\title{
Buku Saku Pencegahan Stunting sebagai Alternatif Media dalam Meningkatkan Pengetahuan Ibu
}

\author{
Indah Purnama Sari*1, Inoy Trisnaini'2, Yustini Ardillah ${ }^{3}$, Sulistiawati \\ 1,2,3Fakultas Kesehatan Masyarakat, Universitas Sriwijaya \\ ${ }^{4}$ Program Studi Kedokteran Gigi, Fakultas Kedokteran, Universitas Sriwijaya \\ *e-mail: indah_purnamasari@fkm.unsri.ac.id ${ }^{1}$
}

\begin{abstract}
Stunting is a chronic malnutrition problem that is caused by the lack of consumption of nutritious food in a long period of time, resulting in growth disorders in children, namely the length of the child is lower or shorter than the standard of age. Stunting on childrens has an impact on brain development disruption by delaying children's motor and cognitive development thereby reducing the quality of Indonesian human resources. The purpose of this activity was to increase the mother's nutritional knowledge in Seberang Ulu I District, Palembang through the provision and explanation of stunting pocket handbooks. The implementation of this activity was through home visits to every household that has a under two years. Knowledge test results showed a significant increase from pre-test and post-test means. This activites showed that the pocket handbook was effective in increasing mother's nutritional knowledge $(p<0,05)$.
\end{abstract}

Keywords: Pocket Handbook, Mother's Knowledge, Stunting

\begin{abstract}
Abstrak
Stunting merupakan masalah kurang gizi kronis yang disebabkan oleh kurangnya konsumsi makanan bergizi dalam kurun waktu yang cukup lama, sehingga mengakibatkan terjadinya gangguan pertumbuhan pada anak yaitu panjang badan anak lebih rendah atau pendek dari standar usianya. Stunting pada anak berdampak pada terganggunya perkembangan otak dengan menunda perkembangan motorik dan kognitif anak sehingga menurunkan kualitas sumber daya manusia Indonesia. Tujuan dari kegiatan ini adalah meningkatkan pengetahuan gizi ibu di Kecamatan Seberang Ulu I Palembang melalui pemberian dan penjelasan buku saku stunting. Adapun pelaksanaan kegiatan ini melalui kunjungan rumah pada setiap rumah tangga yang memiliki baduta. Hasil kegiatan menunjukkan adanya peningkatan yang signifikan dari rata-rata hasil pre-test dan post-test. Hal ini menunjukkan bahwa buku saku efektif dalam peningkatan pengetahuan gizi ibu $(p<0,05)$.
\end{abstract}

Kata kunci: Buku Saku, Pengetahuan Ibu, Stunting

\section{PENDAHULUAN}

Stunting (kerdil) adalah suatu kondisi yang dialami bayi bawah lima tahun (balita) yang memiliki panjang atau tinggi badan yang jika dibandingkan dengan usia lebih dari minus dua standar deviasi median standar pertumbuhan anak dari World Health Organization (WHO). Balita pendek (severe stunting dan stunting) merupakan salah satu permasalahan gizi yang dialami oleh balita tidak hanya di Indonesia namun juga di dunia (Sari, Ardillah, \& Rahmiwati, 2020). Sebanyak 150,8 juta $(22,2 \%)$ anak balita mengalami stunting yang dapat menurunkan sistem kekebalan tubuh, memperlambat pertumbuhan dan mempengaruhi perkembangan otak dan dapat menyebabkan berbagai penyakit tidak menular di masa depan (Ntenda \& Chuang, 2017). Selain itu, stunting juga berdampak pada kesehatan balita baik jangka pendek maupun jangka panjang. Terganggunya perkembangan otak, kecerdasan, gangguan pertumbuhan fisik, dan gangguan metabolisme dalam tubuh merupakan dampak jangka pendek yang akan dialami balita stunting. Sedangkan, untuk jangka panjang adalah menurunnya kemampuan kognitif dan prestasi belajar, menurunnya kekebalan tubuh sehingga mudah sakit, dan risiko tinggi untuk munculnya penyakit diabetes, kegemukan, penyakit jantung dan pembuluh darah, kanker, stroke, dan disabilitas pada usia tua (F. P. Astuti \& Purwaningsih, 2019).

Indonesia masih menghadapi tantangan besar yaitu tingginya prevalensi stunting yang merupakan masalah gizi kronis pada balita yang juga termasuk negara dengan prevalensi stunting tertinggi kedua di Asia Tenggara setelah Kamboja. Hasil Riset Kesehatan Dasar (Riskesdas) 
menunjukkan bahwa prevalensi balita pendek (stunting) berfluktuasi yaitu sebanyak 36,8\% (2007), sebanyak 35,6\% (2010), sebanyak 37,2\% (2013) dan sebanyak 30,8\% (2018). Walaupun terjadi penurunan prevalensi balita pendek (stunting) dalam kurun waktu 2013 dan 2018, namun stunting merupakan masalah kesehatan masyarakat yang dianggap berat $(30 \%$ 39\%)(Kementerian Kesehatan RI, 2018).

Salah satu cara yang dapat dilakukan untuk mencegah stunting pada balita yakni dengan meningkatkan pengetahuan ibu mengenai gizi melalui edukasi gizi. Edukasi gizi yang diberikan dapat menggunakan media edukasi seperti buku saku. Fungsi media dalam pendidikan kesehatan adalah sebagai alat peraga untuk menyampaikan informasi atau pesan-pesan tentang kesehatan. Buku saku merupakan buku dengan ukuran kecil seukuran saku sehingga efektif untuk di bawa kemana-mana dan dapat dibaca kapan saja pada saat dibutuhkan yang dapat berisikan tulisan maupun gambar (N. B. Astuti, Sari, \& Felle, 2019; Rahmawati, Nugraheni, \& Mawarni, 2015). Beberapa hasil penelitian sebelumnya menunjukkan bahwa intervensi pemberian buku saku dapat meningkatkan pengetahuan ibu mengenai gizi (Azadirachta \& Sumarmi, 2017; Eliana \& Solikhah, 2012).

Kegiatan ini dilakukan di Sumatera Selatan yang merupakan salah satu provinsi fokus pemerintah dalam pengendalian masalah stunting pada balita. Hal ini disebabkan oleh karena Provinsi Sumatera Selatan memiliki prevalensi pendek (stunting) lebih tinggi dibandingkan Nasional (31,6\% dan 30,8\%). Sedangkan, berdasarkan hasil Pemantauan Status Gizi (PSG) terdapat peningkatan prevalensi masalah gizi di Kota Palembang yaitu prevalensi pendek (stunting) mengalami peningkatan dari 9,0\% pada tahun 2016 menjadi 14,5\% pada tahun 2017. Kecamatan Seberang Ulu I merupakan salah satu kecamatan di Kota Palembang yang memiliki prevalensi terbanyak ketiga Bawah Garis Merah (BGM) pada balita yang masih lebih tinggi dibandingkan prevalensi di Kota Palembang $(0,66 \%$ dan 0,56\%) dan pada tahun 2017 ditemukan sebanyak 2 balita gizi buruk di kecamatan ini. Hal ini menunjukkan bahwa balita yang berada di Kecamatan Seberang Ulu I masih berisiko untuk menderita masalah gizi terutama stunting, wasting dan underweight (undernutrition) (Pemerintah Kota Palembang Dinas Kesehatan, 2017). Hal ini menunjukkan bahwa pengetahuan ibu mengenai stunting, ASI Eksklusif dan MP-ASI di Kecamatan Seberang Ulu I masih rendah. Sehingga tujuan kegiatan ini adalah mengetahui efektivitas media buku saku dalam meningkatkan pengetahuan ibu mengenai gizi. Hipotesis dalam kegiatan ini adalah terdapat peningkatan rata-rata skor pengetahuan ibu sebelum dan setelah diberikan buku saku pencegahan stunting.

\section{METODE}

Metode pengabdian ini dilakukan dalam bentuk edukasi gizi berupa penyusunan buku saku dan melakukan kunjungan rumah pada setiap rumah tangga yang memiliki baduta dengan memberikan penjelasan mengenai gizi dan permasalahan gizi antara lain ASI eksklusif, MP-ASI dan stunting. Kegiatan ini merupakan tindak lanjut dari kegiatan penelitian yang dilakukan Sari dkk dengan judul Faktor Risiko Undernutrition pada anak usia 6-59 bulan di Kecamatan Seberang Ulu I Palembang. Waktu pengabdian kepada masyarakat dilakukan mulai tanggal 19-27 Oktober 2019. Sebelum kegiatan dilakukan tim pengabdi terlebih dahulu menyusun buku saku yang berjudul "Buku Saku Pencegahan Stunting Melalui Pemberian ASI eksklusif dan MP-ASI pada Baduta". Buku saku ini telah mendapatkan Hak Cipta dengan nomor pencatatan 000158340. Tahap selanjutnya adalah tim pengabdi meminta izin kepada Camat dan Lurah di Kecamatan Seberang Ulu I untuk kelancaran kegiatan pengabdian ini. Peserta kegiatan pengabdian yakni ibu yang memiliki bayi bawah dua tahun yang berjumlah 32 orang. Untuk mengetahui pengetahuan ibu dilakukan dua kali pengukuran yaitu sebelum (pre-test) dan sesudah (post-test) diberikan buku saku dengan selang waktu pengukuran 1 minggu. Alat ukur yang digunkan yakni kuesioner yang terdiri dari identifikai karakteristik ibu, pengetahuan tentang stunting (8 pertanyaan), pengetahuan tentang ASI eksklusif (10 pertanyaan) dan pengetahuan tentang MP-ASI (10 pertanyaan). Pertanyaan mengenai pengetahuan diberikan skor 2 (benar), 1 (salah), 0 (tidak 
tahu) untuk pertanyaan positif dan skor 2 (salah), 1 (benar), 0 (tidak tahu) untuk pertanyaan negatif. Tingkat ketercapaian kegiatan ini dilihat dari adanya perubahan pengetahuan ibu yang dianalisis menggunakan perangkat statistik dengan melakukan Uji Wilcoxon Signed Rank (nilai p $<0,05$ dan interval kepercayaan (CI) 95\%).

\section{HASIL DAN PEMBAHASAN}

Kegiatan pengabdian kepada masyarakat berlangsung dengan baik dan lancar. Hal ini terlihat dari antusias ibu menerima tim pengabdian yang melakukan kunjungan rumah. Tahap awal, tim pengabdian menjelaskan maksud dan tujuan kunjungan rumah yang dilakukan yang kemudian dilanjutkan dengan penandatanganan informed consent. Setelah itu, ibu mengisi kuesioner pengetahuan (pre-test) mengenai ASI eksklusif, MP-ASI dan stunting. Waktu yang dibutuhkan ibu yakni antara 15-20 menit. Setelah mengisi kuesioner (pre-test), tim pengabdian memberikan buku saku dan instruksi kepada ibu bahwa buku saku tersebut menjadi milik ibu dan ibu dapat membacanya setiap saat. Tim pengabdi juga mengingatkan ibu bahwa akan dilakukan kunjungan ulang dalam kurun waktu 1 minggu untuk dilakukan post-test. Tahap akhir adalah pemberian souvenir bagi ibu dan baduta berupa perlengkapan mandi (sabun dan shampoo).

Evaluasi kegiatan pengabdian dapat juga dilihat dari hasil pre-test dan post-test. Hasil kegiatan ini menunjukkan bahwa pengetahuan ibu mengenai stunting mengalami peningkatan lebih dari 50\% untuk pernyataan mengenai ciri anak stunting yang ditandai dengan pertumbuhan yang terlambat (52\%) dan pemberian inisiasi menyusu dini (IMD) dapat mencegah anak menjadi pendek (54\%). Pada pengetahuan ibu mengenai ASI eksklusif, terjadi peningkatan pula yang melebihi 50\% pada penyataan mengenai ASI pertama keluar yang disebut dengan kolostrum $(62,5 \%)$. Berbeda halnya dengan pengetahuan ibu mengenai stunting dan ASI eksklusif, pada pengetahuan ibu mengenai MP-ASI, tidak terjadi peningkatan yang melebihi 50\%.

Hasil pre test dan post test terjelaskan pada Tabel 1. Berdasarkan Tabel 1, rata-rata skor pengetahuan ibu tentang stunting, ASI eksklusif dan MP-ASI sebelum diberikan buku saku masingmasing 6,69 poin dengan simpangan baku sebesar 5,42 poin, 14,25 poin dengan simpangan baku sebesar 4,29 poin, 16,34 poin dengan simpangan baku sebesar 3,56 poin. Setelah diberikan buku saku, rata-rata skor pengetahuan ibu tentang stunting meningkat sebesar 5,15 poin dengan simpangan baku sebesar 5,30 poin. Terjadi peningkatan rata-rata skor pengetahuan ibu tentang ASI eksklusif sebesar 2,75 poin dan rata-rata skor pengetahuan MP-ASI sebesar 0,35 poin dengan simpangan baku masing-masing sebesar 3,27 poin dan 3,22 poin. Adanya peningkatan rata-rata skor pengetahuan setelah diberikan buku saku telah dibuktikan melalui uji hipotesis menggunakan Uji Wilcoxon Signed Rank dengan nilai $\mathrm{p}<0,05$. Namun, hasil statistik ini hanya berlaku bagi pengetahuan ibu tentang stunting dan ASI eksklusif. Sedangkan, peningkatan ratarata skor pengetahuan ibu tentang MP-ASI belum terbukti secara statistik $(0,729>0,05)$. Hasil kegiatan ini menunjukkan bahwa buku saku merupakan salah satu media yang dapat digunakan untuk meningkatkan pengetahuan. 
Tabel 1. Hasil Pre-Post Test Pengetahuan Ibu tentang Stunting, ASI Eksklusif, dan MP-ASI

\begin{tabular}{|c|c|c|c|c|c|}
\hline \multirow[t]{2}{*}{ Variabel } & \multirow[t]{2}{*}{$\mathrm{n}$} & Pre Test & Post Test & $\begin{array}{c}\text { Selisih } \\
\text { antara Post } \\
\text { Test dan Pre } \\
\text { Test }\end{array}$ & \multirow[t]{2}{*}{ Nilai $\mathrm{p}^{*}$} \\
\hline & & Mean $\pm S D$ & Mean $\pm S D$ & Mean $\pm S D$ & \\
\hline $\begin{array}{l}\text { Pengetahuan Ibu tentang } \\
\text { Stunting }\end{array}$ & 32 & $6,69 \pm 5,42$ & $11,84 \pm 3,04$ & $5,15 \pm 5,30$ & 0,000 \\
\hline $\begin{array}{l}\text { Pengetahuan Ibu tentang } \\
\text { ASI Eksklusif }\end{array}$ & 32 & $14,25 \pm 4,29$ & $17,00 \pm 3,13$ & $2,75 \pm 3,27$ & 0,001 \\
\hline $\begin{array}{l}\text { Pengetahuan Ibu tentang } \\
\text { MP-ASI }\end{array}$ & 32 & $16,34 \pm 3,56$ & $16,69 \pm 2,10$ & $0,35 \pm 3,22$ & 0,729 \\
\hline
\end{tabular}

*) Uji Wilcoxon Signed Rank

Sumber: Data Primer, 2019

Pengetahuan merupakan hasil tahu dan terjadi setelah seseorang melakukan pengindraan terhadap objek tertentu dan pengetahuan merupakan domain yang sangat penting dalam membentuk tindakan seseorang yang dapat dilakukan melalui pendidikan kesehatan. Pendidikan kesehatan merupakan proses belajar yang dialami oleh individu, keluarga, kelompok dan masyarakat yang menjadi sasaran dengan tujuan akhir adalah perubahan perilaku. Perubahan pengetahuan dalam kegiatan ini diperoleh dari penggunaan media buku saku. Buku saku yang telah disusun oleh tim pengabdian terdiri dari pengertian stunting, penyebab stunting, ciri-ciri anak stunting, dampak stunting, dan upaya pencegahan stunting. Selain itu, dijelaskan pula mengenai Inisiasi Menyusu Dini (IMD), manfaat IMD, manfaat ASI eksklusif, syarat MP-ASI, dan menu MP-ASI lokal. Tidak hanya tulisan, namun buku saku ini berisi gambar yang menarik. Apriani \& Kumalasari (2015) menyatakan bahwa buku saku merupakan media komunikasi massa yang bertujuan untuk menyampaikan pesan yang bersifat promosi, anjuran, larangan-larangan kepada khalayak massa dalam bentuk buku baik berisi tulisan maupun gambar, sehingga masyarakat memahami dan menerapkan pesan yang terkandung didalam buku saku tersebut sehingga pesan yang disampaikan dapat terserap $83 \%$ dan dapat diingat sebesar 30 . Hasil kegiatan pengabdian kepada masyarakat ini didukung oleh temuan yang menyatakan bahwa informasi yang diberikan dengan menggunakan media buku saku dapat menambah pengetahuan ibu, sehingga semakin sering ibu mendapat informasi gizi dan kesehatan semakin baik pula pengetahuan ibu tentang gizi seimbang untuk balita (Hadisuyitno \& Riyadi, 2018). Selain itu, hasil penelitian Azadirachta \& Sumarmi (2017) menyatakan hasil yang sama dengan kegiatan pengabdian kepada masyarakat ini yakni media buku saku efektif dalam meningkatkan pengetahuan. Hasil kegiatan pengabdian kepada masyarakat yang dilakukan oleh Mitra, Septiani, Susmaneli, \& Nurlisis (2019) menyimpulkan bahwa dengan pemberian edukasi kepada ibu balita dalam mengolah menu MP-ASI dapat meningkatkan pengetahuan dan keterampilan ibu dalam mengolah MP-ASI sehingga dapat meningkatkan status gizi balita dan mencegah balita mengalami stunting.

\section{KESIMPULAN}

Kegiatan pengabdian kepada masyarakat yang dilaksanakan di wilayah kerja Kecamatan Seberang Ulu I Palembang dapat berjalan dengan lancar dan kegiatan ini menyimpulkan bahwa:

1) Buku saku efektif dalam meningkatkan pengetahuan ibu mengenai stunting dan ASI eksklusif, namun belum dapat meningkatkan pengetahuan ibu mengenai MP-ASI.

2) Buku saku yang dilengkapi dengan gambar dan tulisan penuh warna dapat meningkatkan minat ibu untuk membacanya. 
3) Untuk meningkatkan pengetahuan ibu mengenai MP-ASI, perlu dikembangkan buku saku yang dapat digunakan sebagai panduan ibu dalam mempraktikkan pembuatan dan pemberian MPASI pada baduta.

\section{UCAPAN TERIMA KASIH}

Penulis mengucapkan terima kasih kepada Lembaga Penelitian dan Pengabdian Kepada Masyarakat (LP2M) Universitas Sriwijaya yang telah memberi dukungan financial terhadap pengabdian ini dan tim pengabdi yang telah membantu terlaksananya kegiatan pengabdian kepada masyarakat dengan sukses.

\section{DAFTAR PUSTAKA}

Apriani, A., \& Kumalasari, M. L. F. (2015). Pengaruh Pendidikan Kesehatan dengan Booklet Terhadap Pengetahuan dan Sikap tentang Deteksi Dini Kanker Payudara pada WUS di Surakarta Jawa Tengah. Jurnal KesMaDaSka, 6(1), 33-37.

Astuti, F. P., \& Purwaningsih, H. (2019). Peningkatan Pengetahuan Masyarakat Tentang Stunting dan Gizi Balita di Desa Rogomulyo Kecamatan Kaliwungu. Indonesian Journal of Community Empowerment, 1(2), 19-24.

Astuti, N. B., Sari, E. P., \& Felle, G. (2019). Buku Cerita dan Buku Saku sebagai Media Edukasi Gizi untuk Meningkatkan Pengetahuan Sayur dan Buah. Gema Kesehatan, 11(1), 1-7.

Azadirachta, F. L., \& Sumarmi, S. (2017). Pendidikan Gizi Menggunakan Media Buku Saku Meningkatkan Pengetahuan dan Praktik Konsumsi Sayur dan Buah Pada Siswa Sekolah Dasar. Media Gizi Indonesia, 12(2), 107-115.

Eliana, D., \& Solikhah, S. (2012). Pengaruh Buku Saku Gizi Terhadap Tingkat Pengetahuan Gizi Pada Anak Kelas 5 Muhammadiyah Dadapan Desa Wonokerto Kecamatan Turi Kabupaten Sleman Yogyakarta. Kes Mas, 6(2).

Hadisuyitno, J., \& Riyadi, B. D. (2018). Pengaruh Pemakaian Buku Saku Gizi Terhadap Peningkatan Pengetahuan Ibu Balita dan Konsumsi Energi dan Protein Balita. Jurnal Ilmiah-Vidya, 26(2), 60-66.

Kementerian Kesehatan RI. (2018). Situasi Balita Pendek (Stunting) di Indonesia. Jakarta: Pusat Data dan Informasi Kementerian Kesehatan RI.

Mitra, M., Septiani, W., Susmaneli, H., \& Nurlisis, N. (2019). Meningkatkan Status Gizi Balita Melalui Praktek Pengolahan Makanan Pendamping ASI Buatan Sendiri. DINAMISIA: Jurnal Pengabdian Kepada Masyarakat, 3(2), 208-213.

Ntenda, P., \& Chuang, Y.-C. (2017). Analysis of Individual-level and Community-level Effects on Childhood Undernutrition in Malawi. Pediatrics \& Neonatology, 59, 380-389.

Pemerintah Kota Palembang Dinas Kesehatan. (2017). Profil Kesehatan Tahun 2016. Palembang: Dinas Kesehatan Kota Palembang.

Rahmawati, N. I., Nugraheni, S. A., \& Mawarni, A. (2015). Pengaruh Penggunaan Buku Saku oleh Motivator terhadap Pengetahuan dan Keterampilan Motivator dalam Mengatasi Permasalahan Pemberian ASI (di Kecamatan Sewon Kabupaten Bantul). Jurnal Ners dan Kebidanan Indonesia, 3(2), 64-70.

Sari, I. P., Ardillah, Y., \& Rahmiwati, A. (2020). Berat Bayi Lahir dan Kejadian Stunting pada Anak Usia 6-59 Bulan di Kecamatan Seberang Ulu I Palembang. Jurnal Gizi Indonesia, 8(2), 110-118. 